\title{
The Effect of Assessment Type (self vs. peer vs. teacher) on Iranian University EFL Students' Course Achievement
}

\author{
ZAINAB ABOLFAZLI KHONBI \& KARIM SADEGHI \\ Urmia University, Iran
}

\section{Bio Data:}

Zainab Abolfazli Khonbi has an MA in TEFL from Urmia University. She is interested in alternative assessment and language testing.

Karim Sadeghi lectures at English Language Department of Urmia University. He has a PhD in Applied Linguistics from the University of East Anglia, UK. His publications have appeared in TESL Canada Journal, Asian EFL Journal, IJAL, TELL, ASIA Pacific Education Researcher, and The Modern Language Journal among others. He is the editor-inchief of Iranian Journal of Language Teaching Research.

\begin{abstract}
This research investigated the effect of self-, peer-, and teacherassessment on Iranian undergraduate EFL students' course achievement. Four intact classes, including 82 students from Urmia, Tabriz, and Tabriz Islamic Azad universities were randomly assigned into one of the self-, peer-, teacher-assessment, or control groups. The students were pretested on their current Teaching Methods knowledge. After receiving relevant instruction and training, the first experimental group $(\mathrm{N}=21)$ were involved in self-assessment activities, the second one $(\mathrm{N}=23)$ were engaged with peer-assessment tasks, and the third one $(\mathrm{N}=21)$ were subjected to teacher-assessment; however, the control group $(\mathrm{N}=19)$ received no assessment-related treatment. The application of ANCOVA on the results of the achievement posttest indicated differences in the performances of peer-, self-, teacherassessment, and the control groups $F(3,77)=23.15, p=.05$, in favour of peer-assessment. A medium effect size was found between the independent and dependent variables (partial eta squared $=.47$ ); however, the covariate, albeit significant (.03), had a small effect size (partial eta squared $=.05)$. Further findings and implications are discussed in the paper.
\end{abstract}

Keywords: Alternative assessment; Course achievement; EFL students; Peer-assessment; Self-assessment; Teacher-assessment 


\section{Introduction}

In educational systems, assessment is an inevitable ingredient because it may influence learning, and when made authentic it provides feedback and revision to improve learning. Furthermore, through meaningful engagement of students in the learning process, assessment can affect motivation. Assessment would also enhance instruction by helping the teacher recognize students' weaknesses and strengths. Assessments can also be made valid, fair, ethical, feasible, and efficient tools for learning using multiple measures (Mousavi, 2012).

It has been argued that learning how to learn (self-directed learning) would be of utmost importance for language learners for at least three reasons. First, because of the complexity of the task which learning presents, there is never enough time within a formal scheme of instruction to ensure mastery on the part of students, and if the learner has not been prepared within the classroom to take responsibility to learn autonomously outside, it is unlikely that any learning will take place (Dickinson \& Carver, 1980; Carver \& Dickinson, 1982). The second reason is the belief that engaging students in the process of learning and assessment would encourage their learning efficiency. Studies of the characteristics of good language learners (Stern, 1975; Naiman, et al. 1978; Stern, 1983) suggest that efficient learners consciously monitor their performances, analyze them, and develop a repertoire of efficient learning strategies. Thirdly, in a self-directed scheme, through reducing the distance between the learner and the teacher, feelings of anxiety, frustration, and alienation decrease, and consequently the learner becomes more receptive to the learning process (Brown, 1973; Schumann, 1975).

The present research investigated the effect of three types of assessments, namely, self, peer, and teacher, on Iranian university EFL students' course achievement. Indeed, student-centred approaches in language teaching led the field of language testing to a shift of paradigm from traditional psychometric (teachercentered) testing to alternative edumetric (student-centered) assessment (Farhady, 2006; McNamara, 2000; Brown \& Hudson, 1998). The implementation of studentdirected assessment arises out of a faith in student autonomy as an educational goal (see Boud, 1981). Powell (1981, p.209), summarizing the value of this approach, claims that:

The promotion of independent learning is . . central to the whole enterprise of higher education because the intellectual powers which it seeks to foster cannot (logically cannot) be exercised except in an independent mode. Critical thinking, judgement, creativeness, initiative, interpretative skills, hypothesis formulation and problem-solving capacities can only be made manifest by someone who is operating independently.

Research studies involving peer- and self-assessment have indicated that in order to enable students to perform these tasks effectively, they need training and experience (Jafarpur, 1991; Adams \& King, 1995; Freeman, 1995; Pond et al., 1995). They have also revealed that peer- (and self-) assessment can work toward developing students' higher order reasoning and higher level cognitive thought (Birdsong \& Sharplin, 1986), helping nurture student-centred learning among undergraduate learners (Oldfinch \& MacAlpine, 1995), encouraging active and 
flexible learning (Entwhistle, 1993) and facilitating a deep approach to learning rather than a surface approach (Entwhistle, 1987; Gibbs, 1992).

Applying student-directed assessment for improving students' course achievement may signify that self-assessment is particularly good for 'low-stakes' assessment: 'Low stakes' assessment would include formative assessment, where the students' performance in the assessment task in question is not considered in the calculation of their overall mark for the course. Roever (2001, p. 90) is of the belief that self-assessment is less appropriate for medium- and high-stakes assessment. Medium-stakes assessment is defined as that which affects students' lives, though not radically so (for example, mid-term examinations), and high-stakes assessment as that which can have life-altering potential (e.g. final examinations for a degree).

Self-assessment is an assessment technique that refers to the process whereby "learners simultaneously create and undergo the evaluation procedure, judging their achievement in relation to themselves against their own personal criteria, in accordance with their own objectives and learning expectations" (Henner-Stanchina \& Holec, 1985, p. 98). According to Topping (1998), peer-assessment is an arrangement in which individuals consider the amount, level, worth, and quality of success of the products or outcomes of learning of peers of similar status.

Curriculum developers and syllabus designers in general and course designers and university professors in particular may feel the need to pay more attention to students' needs and styles, since they may somehow act as contributing factors to the students' ultimate academic success; therefore there is a necessity for research to let the students gain autonomy in and self-awareness of their learning.

Therefore, to clarify what the story is in an EFL university context, and to contribute to the growing body of work in the field, the present research was aimed to answer the following question: Is there any statistically significant difference among self-, peer-, and teacher-assessment on Iranian university EFL students' course achievement? The question was tentatively answered in the form of a null hypothesis as follows to be tested at 0.05 level of significance: There is no significant difference among self-, peer, and teacher-assessment on Iranian university EFL students' course achievement.

\section{Method}

\section{Participants}

The participants were 82 male and female EFL students at Urmia, Tabriz, and Tabriz Islamic Azad universities, West and East Azarbaijan Provinces, Iran, working for a BA in English Language and Literature. They were within the age range of 20 to 22 . There were 19, 23, 21, and 19 candidates in the self-, peer, teacher-assessment, and the control groups, respectively.

\section{Instruments}

The particular course of interest was Teaching Methodology course for which Techniques and Principles in Language Teaching (Larsen-Freeman, 2006) was used as the instructional material as a four-unit credit bearing course. The two other materials used were the pretest (knowledge test) and the posttest (course achievement test), both included in the appendix. The tests paralleled each other, were content valid to a satisfactory degree and enjoyed a phi(lambda) dependability 
index (Brennan, 1980, 1984, 2001) of .90. This formula is the only squared-error loss agreement index for criterion-referenced tests that have a single test administration.

\section{Procedure}

This study followed a semi-experimental intact group design in which the classes were randomly assigned into either self-, peer-, teacher-assessment, or control group. At the beginning of the term, all the groups had a pretest which measured the students' existing knowledge of the specific course book. Then, in the self-, and peerassessment groups, the students were trained on how to assess themselves as well as their peers, respectively. For example the students were informed that they will have an assessment every two units covered from the course book, and they are free to construct items of any type. While in the self-assessment group, they were instructed to make, answer and mark their own papers, in the peer-assessment group, the candidates were instructed to answer tests made and marked by anonymous peers. In the teacher-assessment group, however, the teacher was asked to design and mark the papers.

The students in the first experimental group were required to make and bring to the class pre-designed papers based on the first two units covered, with items in any format. The papers were collected. This procedure was repeated for the next two-unit-based papers. In the third assessment session, while they were expected to deliver their third two units-based papers, their first assessment papers were reviewed by their peers in order to check any obviously faulty items. Then each student began to answer his first paper and when finished, they were again reviewed by peers to mark any unanswered items. When the process was over, each student marked his own paper and his score was recorded by the researchers. No one expressed dissatisfaction with his scores and there was no further feedback. In each assessment session, the same procedure was followed.

In the second experimental group, students were required to design tests at home with items of any type. In each assessment session, when the papers were brought to the class, they were collected, and students' names were taken apart. After assigning each student's name with a code in a notebook, the papers were distributed among their peers, again writing a new code in front of each previously given paper. Meanwhile, care was taken not to give any paper to its own designer. When students had finished answering, the papers were given to their designers for marking. Finally, based on the codes, students were allowed to review their papers to eliminate any mismarking. There was negotiation among students, giving justifications by both the assessors (for the marks they had given) and assessees (for the answers they had written). When any dissatisfaction was resolved, the scores were recorded by the researchers. The next three assessments were conducted in the same way.

In the third experimental group, however, the tests were made by the researchers, then checked by the teacher and modified accordingly. In each assessment session, when students finished answering, the papers were collected and marked by the researchers. Every next assessment session, previous assessment scores were reported to the students; however, no one seriously criticized his score and no one wanted to receive feedback as to the right answers. The procedure was 
similarly followed for the next three assessment sessions. Having received an assessment every two units, the three experimental groups took four assessment series during the term. The control group had no assessment during the semester. Finally, at the end of the term, all groups took the posttest.

\section{Results}

One way analysis of variance (ANOVA) was run to explore the differences in the four groups' mean scores on the pretest in order to figure out whether any initial differences existed between groups. Table 1 shows descriptive statistics for the pretest in all four groups and Figure 1 is a visual representation of the four groups' mean scores on the pretest.

Table 1

Descriptive statistics for the pretest

\begin{tabular}{|c|c|c|c|c|c|c|c|c|}
\hline \multicolumn{9}{|c|}{ Descriptive } \\
\hline \multicolumn{9}{|c|}{ Pretest scores } \\
\hline & $\mathrm{N}$ & Mean & Std. & Std. & $95 \%$ & Confidence & Minimum & Maximum \\
\hline & & & Deviation & Error & \multicolumn{4}{|c|}{ Interval for Mean } \\
\hline & & & & & Lower & Upper & & \\
\hline & & & & & Bound & Bound & & \\
\hline self & 19 & 6.8305 & 2.13973 & .49089 & 5.7992 & 7.8618 & 4.00 & 12.00 \\
\hline peer & 23 & 5.3465 & 1.84401 & .38450 & 4.5491 & 6.1439 & .58 & 9.15 \\
\hline teacher & 21 & 4.5476 & 1.72008 & .37535 & 3.7646 & 5.3306 & .00 & 7.43 \\
\hline control & 19 & 5.3584 & 1.23753 & .28391 & 4.7620 & 5.9549 & 2.29 & 6.86 \\
\hline Total & 82 & 5.4885 & 1.91664 & .21166 & 5.0674 & 5.9097 & .00 & 12.00 \\
\hline
\end{tabular}

\section{groups' pretest mean scores}

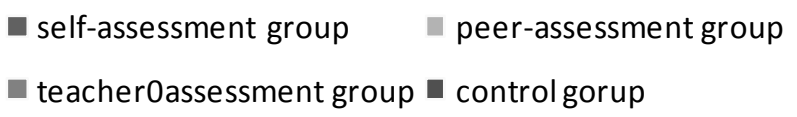

teacher0assessment group $\mathbf{\text { control gorup }}$

6.83

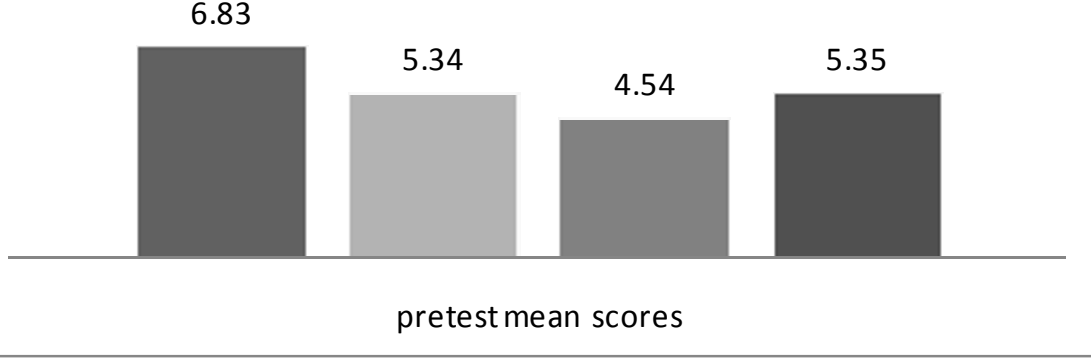

Figure 1. Groups' mean scores on the pretest

As indicated in table 2, significant differences (at $\mathrm{p}<0.05$. level) were found among four groups' mean scores on the pretest: $F(3,78)=5.71, p=.001$. 
Table 2

ANOVA for the pretest

\begin{tabular}{llllll}
\hline ANOVA & & & & & \\
\hline Pretest scores & & & & & \\
& Sum of Squares & df & Mean Square & F & Sig. \\
Between Groups & 53.595 & 3 & 17.865 & 5.712 & $\mathbf{. 0 0 1}$ \\
Within Groups & 243.960 & 78 & 3.128 & & \\
Total & 297.556 & 81 & & & \\
\hline
\end{tabular}

The results of post-hoc tests (table3) indicated a significant difference (sig. $=.041$ ) between self-assessment $(M=6.83, S D=2.13)$ and peer-assessment groups $(M=5.34$, $\mathrm{SD}=1.84)$. In addition, a significant difference (sig. $=.001)$ was also found between self-assessment $(\mathrm{M}=6.83, \mathrm{SD}=2.13)$ and teacher-assessment groups $(\mathrm{M}=4.54, \mathrm{SD}=$ 1.72). However, control group $(\mathrm{M}=5.35, \mathrm{SD}=1.23)$ did not differ significantly from eitherself-, peer-, or teacher-assessment groups. Peer-assessment $(M=5.34, S D=1.84)$ group was also found to have no significant difference from teacher-assessment group.

Table 3

Multiple comparisons for the pretest

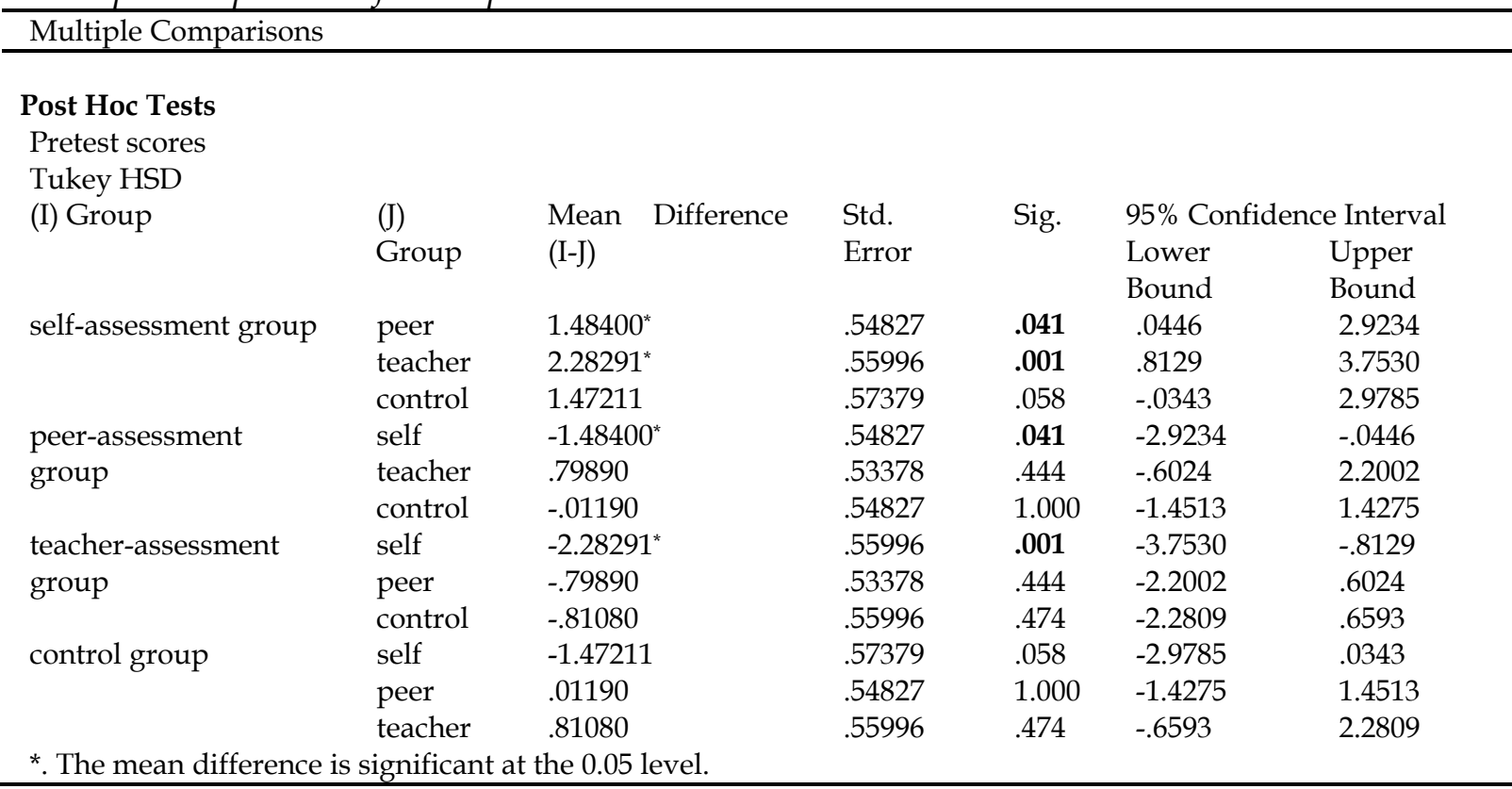

For the four series of assessments, one-way ANOVAs were used to compare the experimental groups' mean scores on the associated assessments. Table 4 shows descriptive statistics for the four series of assessments in the self-, peer-, and teacherassessment groups and Figure 2 is a visual representation of the three experimental groups' mean scores on the four series of assessments. 
Table 4

Descriptive statistics for the four series of assessments

\begin{tabular}{|c|c|c|c|c|c|c|c|c|c|}
\hline \multicolumn{10}{|l|}{ Descriptive } \\
\hline & & $\mathrm{N}$ & Mean & $\begin{array}{l}\text { Std. } \\
\text { Deviation }\end{array}$ & $\begin{array}{l}\text { Std. } \\
\text { Error }\end{array}$ & $\begin{array}{l}95 \% \\
\text { Interval }\end{array}$ & $\begin{array}{l}\text { Dnfidence } \\
\text { Mean }\end{array}$ & Minimum & Maximum \\
\hline & & & & & & Lower & Upper & & \\
\hline \multirow[t]{4}{*}{$\begin{array}{l}\text { First } \\
\text { assessment }\end{array}$} & self & 19 & 18.4211 & 2.00875 & .46084 & 17.4529 & 19.3892 & 14.00 & 20.00 \\
\hline & peer & 20 & 16.8250 & 2.82505 & 63170 & 15.5028 & 18.1472 & 12.00 & 20.00 \\
\hline & teacher & 21 & 14.6676 & 1.58632 & .34616 & 13.9455 & 15.3897 & 11.40 & 16.30 \\
\hline & Total & 60 & 16.5753 & 2.65853 & .34321 & 15.8886 & 17.2621 & 11.40 & 20.00 \\
\hline \multirow{4}{*}{$\begin{array}{l}\text { Second } \\
\text { assessment }\end{array}$} & self & 17 & 19.4706 & 1.12459 & .27275 & 18.8924 & 20.0488 & 16.00 & 20.00 \\
\hline & peer & 21 & 16.1429 & 4.22535 & .92205 & 14.2195 & 18.0662 & 7.00 & 20.00 \\
\hline & teacher & 21 & 15.0952 & 2.68616 & .58617 & 13.8725 & 16.3180 & 10.00 & 18.50 \\
\hline & Total & 59 & 16.7288 & 3.50532 & .45635 & 15.8153 & 17.6423 & 7.00 & 20.00 \\
\hline \multirow{4}{*}{$\begin{array}{l}\text { Third } \\
\text { assessment }\end{array}$} & self & 18 & 19.4444 & 1.14903 & .27083 & 18.8730 & 20.0158 & 16.00 & 20.00 \\
\hline & peer & 17 & 17.1294 & 3.52629 & .85525 & 15.3164 & 18.9425 & 9.00 & 20.00 \\
\hline & teacher & 21 & 15.9048 & 1.84132 & .40181 & 15.0666 & 16.7429 & 13.00 & 20.00 \\
\hline & Total & 56 & 17.4143 & 2.73904 & .36602 & 16.6808 & 18.1478 & 9.00 & 20.00 \\
\hline \multirow{4}{*}{$\begin{array}{l}\text { Fourth } \\
\text { assessment }\end{array}$} & self & 16 & 18.3750 & 4.20912 & 1.05228 & 16.1321 & 20.6179 & 4.00 & 20.00 \\
\hline & peer & 20 & 17.9750 & 3.37356 & .75435 & 16.3961 & 19.5539 & 9.00 & 20.00 \\
\hline & teacher & 21 & 15.5000 & 2.02312 & .44148 & 14.5791 & 16.4209 & 11.50 & 19.00 \\
\hline & Total & 57 & 17.1754 & 3.42940 & .45424 & 16.2655 & 18.0854 & 4.00 & 20.00 \\
\hline
\end{tabular}

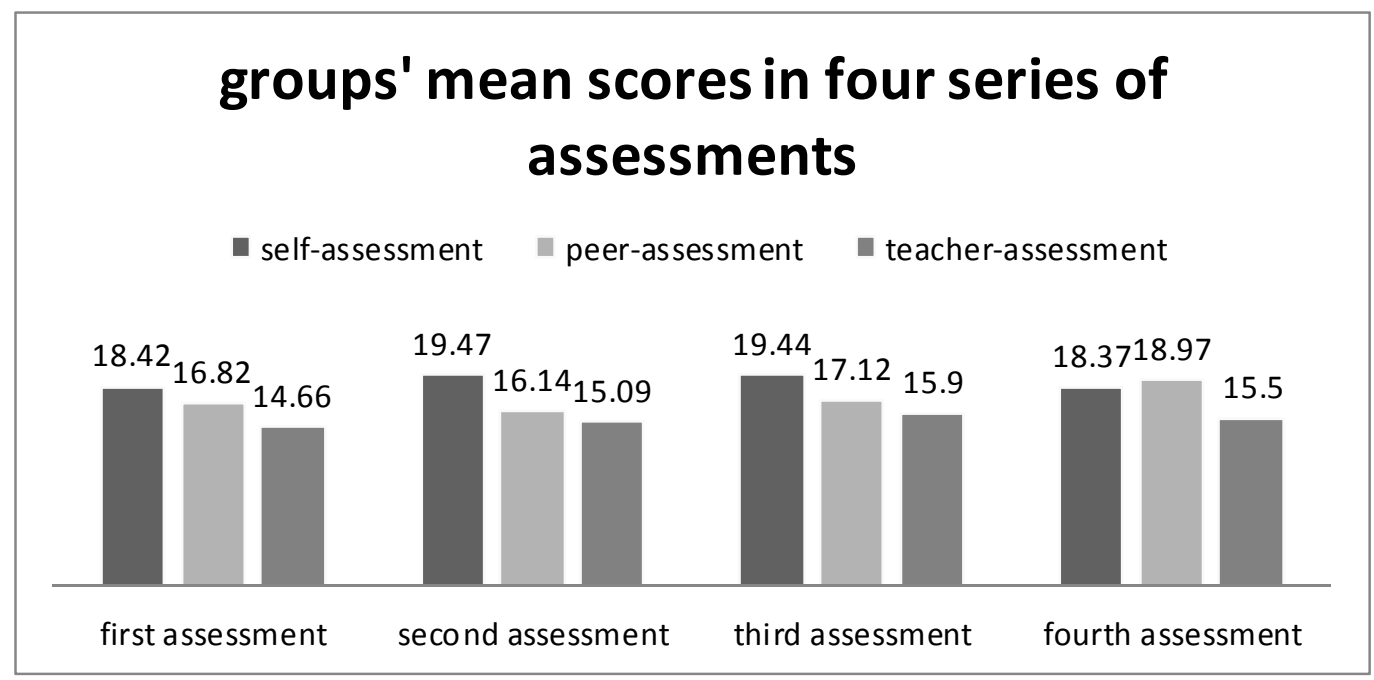

Figure 2. Self-, peer-, and teacher-assessment groups' mean scores in four assessment series

The results of one-way ANOVA for the four series of assessments at the $p<.05$ are presented in table 5 . 
Table 5

ANOVA for the four assessments

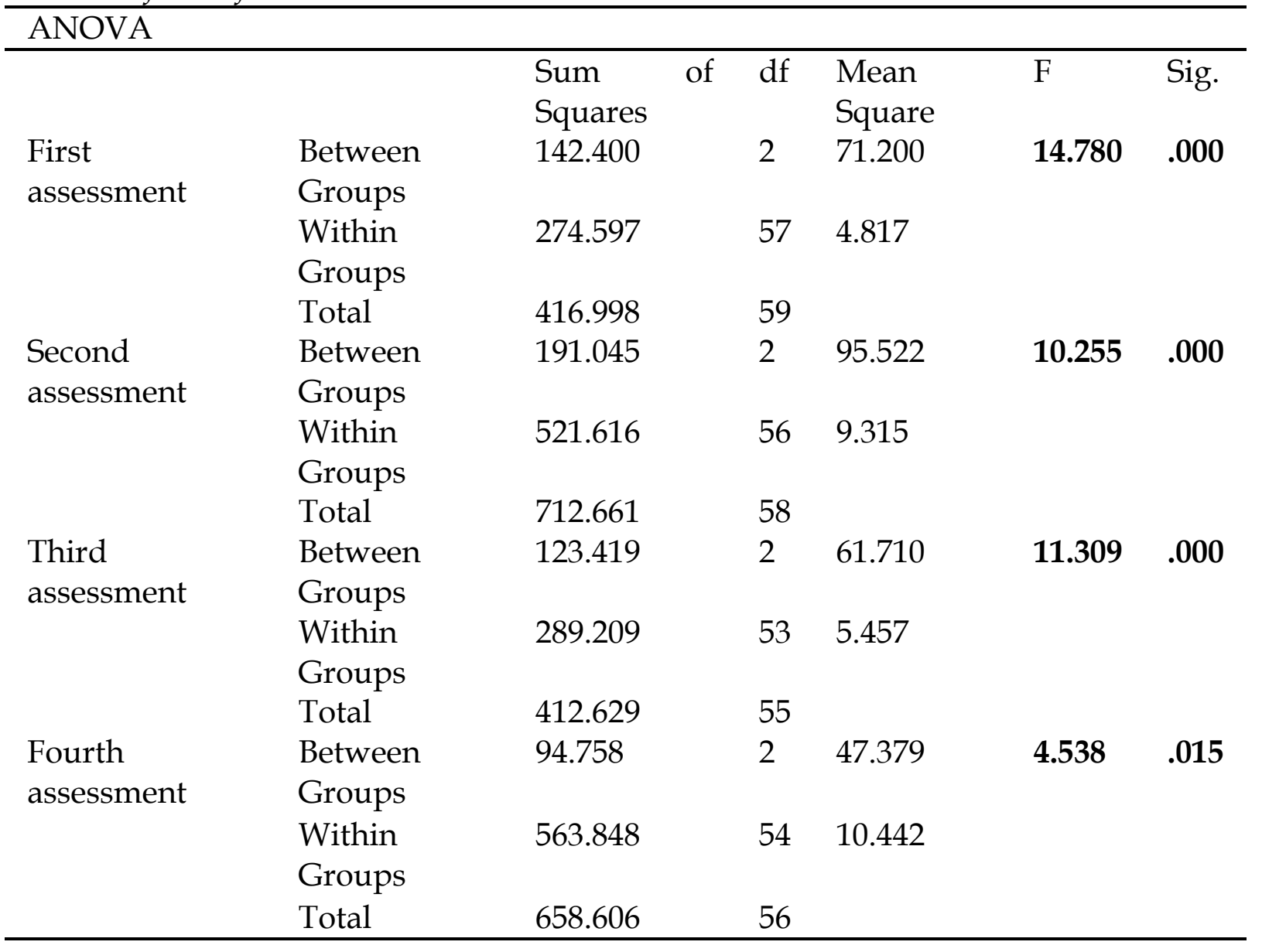

Table 6 shows the result of post-hoc test for the four series of assessments. 
Table 6

Post Hoc Tests

\begin{tabular}{|c|c|c|c|c|c|c|c|}
\hline \multicolumn{8}{|c|}{ Multiple Comparisons } \\
\hline \multicolumn{8}{|l|}{ Tukey HSD } \\
\hline \multirow{3}{*}{$\begin{array}{l}\text { Dependent } \\
\text { Variable }\end{array}$} & \multirow{3}{*}{$\begin{array}{l}\text { (I) } \\
\text { Group }\end{array}$} & \multirow{3}{*}{$\begin{array}{l}\text { (J) } \\
\text { Group }\end{array}$} & \multirow{3}{*}{$\begin{array}{l}\text { Mean } \\
\text { Difference (I-J) }\end{array}$} & \multirow{3}{*}{$\begin{array}{l}\text { Std. } \\
\text { Error }\end{array}$} & \multirow[t]{3}{*}{ Sig. } & \multicolumn{2}{|c|}{ 95\% Confidence Interva } \\
\hline & & & & & & Lower & Upper \\
\hline & & & & & & Bound & Bound \\
\hline \multirow{6}{*}{$\begin{array}{l}\text { First } \\
\text { assessment }\end{array}$} & \multirow[t]{2}{*}{ self } & peer & 1.59605 & .70316 & .068 & -.0960 & 3.2881 \\
\hline & & teacher & $3.75343^{*}$ & 69495 & .000 & 2.0811 & 5.4258 \\
\hline & \multirow[t]{2}{*}{ peer } & Self & -1.59605 & .70316 & .068 & -3.2881 & .0960 \\
\hline & & Teacher & $2.15738^{*}$ & .68577 & .007 & .5071 & 3.8076 \\
\hline & \multirow[t]{2}{*}{ teacher } & self & $-3.75343^{*}$ & 69495 & .000 & -5.4258 & -2.0811 \\
\hline & & peer & $-2.15738^{*}$ & .68577 & .007 & -3.8076 & -.5071 \\
\hline \multirow{6}{*}{$\begin{array}{l}\text { Second } \\
\text { assessment }\end{array}$} & \multirow[t]{2}{*}{ self } & peer & $3.32773^{*}$ & .99572 & .004 & .9305 & 5.7250 \\
\hline & & teacher & $4.37535^{*}$ & .99572 & .000 & 1.9781 & 6.7726 \\
\hline & \multirow[t]{2}{*}{ peer } & Self & $-3.32773^{*}$ & .99572 & .004 & -5.7250 & -.9305 \\
\hline & & teacher & 1.04762 & .94186 & .511 & -1.2200 & 3.3152 \\
\hline & \multirow[t]{2}{*}{ teacher } & Self & $-4.37535^{*}$ & .99572 & .000 & -6.7726 & -1.9781 \\
\hline & & peer & -1.04762 & .94186 & .511 & -3.3152 & 1.2200 \\
\hline \multirow{6}{*}{$\begin{array}{l}\text { Third } \\
\text { assessment }\end{array}$} & \multirow[t]{2}{*}{ self } & peer & $2.31503^{*}$ & .79003 & .014 & .4101 & 4.2200 \\
\hline & & teacher & $3.53968^{*}$ & .75033 & .000 & 1.7304 & 5.3489 \\
\hline & \multirow[t]{2}{*}{ peer } & Self & $-2.31503^{*}$ & .79003 & .014 & -4.2200 & -.4101 \\
\hline & & teacher & 1.22465 & .76212 & .252 & -.6130 & 3.0623 \\
\hline & \multirow[t]{2}{*}{ teacher } & Self & $-3.53968^{*}$ & .75033 & .000 & -5.3489 & -1.7304 \\
\hline & & Peer & -1.22465 & .76212 & .252 & -3.0623 & .6130 \\
\hline \multirow{6}{*}{$\begin{array}{l}\text { Fourth } \\
\text { assessment }\end{array}$} & \multirow[t]{2}{*}{ self } & peer & .40000 & 1.08383 & .928 & -2.2120 & 3.0120 \\
\hline & & teacher & $2.87500^{*}$ & 1.07230 & .026 & .2908 & 5.4592 \\
\hline & \multirow[t]{2}{*}{ peer } & Self & -.40000 & 1.08383 & .928 & -3.0120 & 2.2120 \\
\hline & & teacher & $2.47500^{*}$ & 1.00960 & .045 & .0419 & 4.9081 \\
\hline & \multirow[t]{2}{*}{ teacher } & Self & $-2.87500^{*}$ & 1.07230 & .026 & -5.4592 & -.2908 \\
\hline & & peer & $-2.47500^{*}$ & 1.00960 & .045 & -4.9081 & -.0419 \\
\hline
\end{tabular}

Based on the above two tables (5 and 6), the significant differences among the groups' mean scores, along with ANOVA results, are summarized below.

On the first assessment, teacher-assessment group $(\mathrm{M}=14.66, \mathrm{SD}=1.58)$ differed significantly (sig. $=.000)$ from self-assessment group $(\mathrm{M}=18.42, \mathrm{SD}=2.00)$ and (sig.= 007 ) from peer-assessment group $(\mathrm{M}=16.82, \mathrm{SD}=2.82)$ : $\mathrm{F}(2,57)=14.78, \mathrm{p}=.00$.

On the second assessment, self-assessment group $(\mathrm{M}=19.47, \mathrm{SD}=1.12)$ differed significantly (sig. $=.000)$ from teacher-assessment group $(\mathrm{M}=15.09, \mathrm{SD}=2.68)$ and (sig.= .004) from peer-assessment group $(\mathrm{M}=16.14, \mathrm{SD}=4.22): \mathrm{F}(2,56)=10.25, \mathrm{p}=00$.

On the third assessment, self-assessment group $(\mathrm{M}=19.44, \mathrm{SD}=1.14)$ differed significantly (sig. $=.000)$ from teacher-assessment group $(\mathrm{M}=15.90, \mathrm{SD}=1.84)$ and (sig.= .014) from peer-assessment group $(\mathrm{M}=17.12, \mathrm{SD}=3.52): \mathrm{F}(2,53)=11.30, \mathrm{p}=$ .00 .

On the fourth assessment, it was the teacher-assessment group $(\mathrm{M}=15.50, \mathrm{SD}=2.02)$ that had a significantly different performance (sig.= .021) from self-assessment group 
$(\mathrm{M}=18.37, \mathrm{SD}=4.20)$ and $($ sig. $=.045)$ from peer-assessment group $(\mathrm{M}=17.97, \mathrm{SD}=$ 3.37): $\mathrm{F}(2.54)=4.53, \mathrm{p}=.01$.

Since the groups' mean scores differed significantly in the pretest, at the posttest stage, one-way between groups analysis of covariance (ANCOVA) was employed to compare the groups' mean scores. Table 7 reveals the groups' characteristics on the posttest. The independent variable was the type of assessments (self vs., peer, vs. teacher), and the dependent variable was scores on the posttest. Students' mean scores on the pretest were used as the covariate in this analysis. The same information is graphically represented in Figure 3.

Table 7

Descriptive statistics for the posttest

\begin{tabular}{|c|c|c|c|}
\hline \multicolumn{4}{|l|}{ Descriptive Statistics } \\
\hline \multicolumn{4}{|l|}{ Dependent Variable:Posttest } \\
\hline Group & Mean & Std. Deviation & $\mathrm{N}$ \\
\hline self-assessment-group & 16.2632 & 1.92071 & 19 \\
\hline peer-assessment group & 17.3478 & 1.36611 & 23 \\
\hline teacher-assessment group & 14.9648 & 1.41877 & 21 \\
\hline control group & 13.2947 & 1.81521 & 19 \\
\hline Total & 15.5471 & 2.20790 & 82 \\
\hline
\end{tabular}

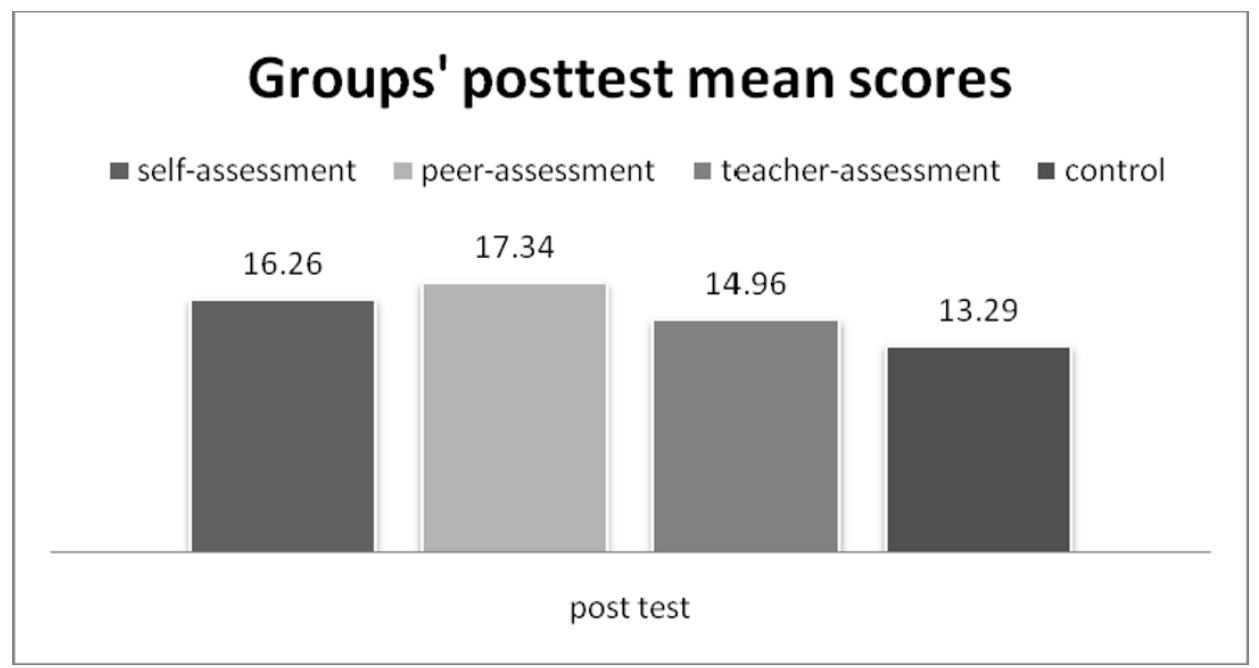

Figure 3. Groups' mean scores on the posttest

Preliminary checks were conducted to ensure that there was no violation of the assumptions of normality, linearity, homogeneity of variances. After adjusting for pretest scores, since the significance value corresponding to the posttest scores was $p=.00$, there was a significant difference among self-, peer-, teacher-assessment and the control groups' mean scores $F(3,77)=23.15, p=.000$. The corresponding effect size (partial eta squared) was .47, which according to Cohen's (1988) classification indicated a medium effect. In fact, $47 \%$ of the variance in the groups' mean scores on the posttest was due to the type of assessment. Although the 
influence of the groups' mean scores on the pretest was significant ( $\mathrm{p}=.03)$, it had a small relationship with the posttest scores. These results are displayed in table 8 .

Table 8

ANCOVA results for the post-test

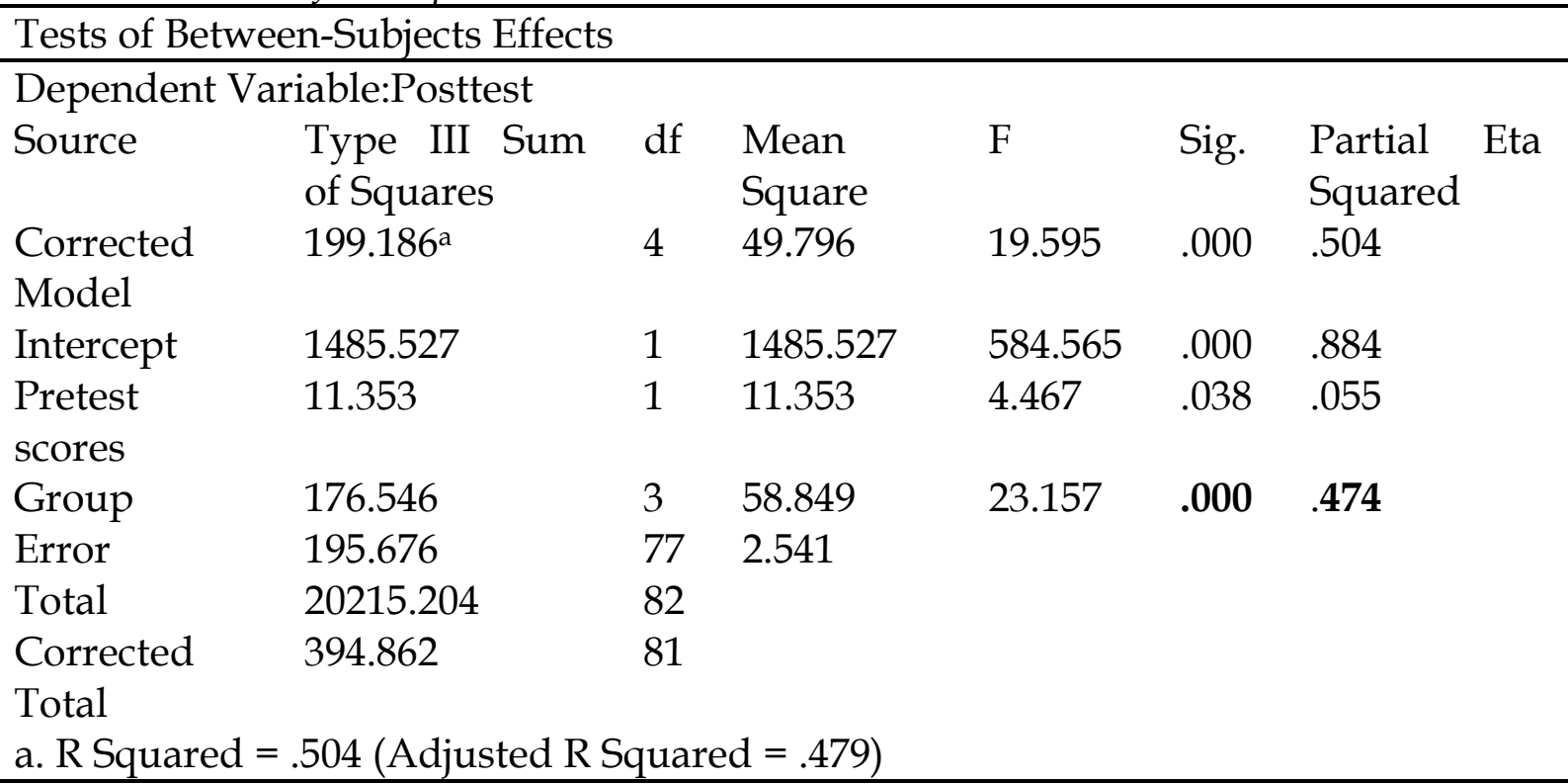

\section{Discussion and Conclusion}

The results showed that during the four assessment series, self-assessment group had the highest mean scores in the first three followed by peer-assessment group but for the last assessment, peer-assessment group overperformed the other groups. Meanwhile, teacher-assessment group had the lowest mean scores in all series of assessments. On the posttest, peer-assessment group outperformed all the other groups, followed by self-assessment, thenteacher-assessment, and finally the control group that had the lowest mean score (all the differences were significant statistically). Postest data analysis revealed that the type of assessment had a medium effect on the results, while the pretest scores had a small effect size. Therefore, the null hypothesis was rejected and the type of assessment proved to have an effect (in favour of peer-assessment) on Iranian university EFL students' course achievement. Based on the observations we had in this research, we can offer the following tentaive conclusions, although we believe that replication of this study in other contexts will lead to a better understanding of the role of assessment type in course achievement.

It can be concluded that among the many likely reasons, students in selfassessment (SA) group did not take the assessment serious(e.g., Butler \& Lee, 2010; Dann, 2002) and this might have led to their surface-level study. Theteachers could design ways to better enable students to realize the reasons for the assessment (e.g., by telling them that they have the power to influence instruction). Another reason may be the lack of feedback in this group compared to peer-assessment (PA) group that limited the effectiveness of SA. The teachers may negotiate papers with students or exercise peer-feedback (e.g., Butler \& Lee, 2010; Black \& William, 1998). 
The presence of some competitive environment among the students in PA group and their willingness to assess their peers' achievement as accurately as possible led them to have more in-depth study and to be strict both in item construction and designing measurement criteria - two elements which certainly affects the effecicency of an assessment practice(e.g., Blanche \& Merino, 1989; Oscarson, 1997; Ross, 1998).

Among the many elements that might have affected the students' performences in the teacher-assessment group, it seemed that the teacher had designed more difficult items and assessed the students with much strictness. If it was the case, so students ought to have study harder, but this was not substantiated by posttest scores. Such a finding can be attributed to the introduction between selfand peer-assessment, which were new to the students in their associated groups, promoting self-regulatory learning and autonomy (e.g., Dann, 2002; Oscarson, 1989, 1997; Paris \& Paris, 2001) and leading to the claim that learning advances from assessing one's own and others' performances (Stone Wiske, 1999).

Abolfazli and Sadeghi (2012) also found that when self-assessment is compared with peer-assessment in terms of their effect on students' course achievement scorses, it is the latter that proves to be more influential. The same results were also forund by Chang et al. (2012) on portfolio assessment in which they found that peer-assessment group had the highest mean scores followed by selfassessment and the teacher-assessment with lowest scores. Similarly, Chang et al. (2012) and Sadler and Good (2006) reported that peer-raters are stricter than selfraters. Peer-evaluation of writing has also been found to have a significant impact on the improvement of the student writers (Brown, 2001; Patri, 2002).

The difference in the performance of students in the self-and peer-assessment group in the present research can be comaprable also with Patri's (2002) study on the influence of peer-feedback on self-and peer-assesment, where it was claimed that the behaviour of peer-assessment was different from that of self-assessment. Consistent with the findings of the present research, Lin et al. (2001) found that students in the self-and peer-groups had different performances and stated that a possible reason for the difference is that self-assessment is based on a more lax scoring standard than peer-assessment. Sadler and Good's (2006) study, supporting the findings of the present research, revealed that peer-based scores were lower than self-based scores, which may mean that peer-raters tend to under-grade while self-raters tend to overgrade.

A finding of this study that teacher-assessment groups' scores were the lowest on the series of assessments, and that this might have been as a result of the teacher's strictness in scoring is in line with (but the other finding that self-assessors used a more lax scoring standard than peer-assessors did is in sharp contrast to)findings by Chang et al. (2012), Lin et al. (2001), and Sadler and Good (2006). In their study they found that the teacher-scoring was the strictest, and peer-scoring was the most lax, with self-scoring in between, showing that peer-raters tended to adopt more lax scoring standards than self-raters did. In contrast with the results of the present research, Pond et al.(1995) and Falchikov (1995) found peers less strict in assessing eachother. They even defined this over-marking by peers as 'friendship marking' or 'decibel marking', and claimed that this could be because peers found it difficult to 
criticize their friends. The divergent outcomes above may probably be due to the various educational levels of students, students' and teachers' attitudes toward and beliefs about the assessment methods, the assessment environments, assessor trainings, no previous autonomous learning experience, etc.

A major limitation of the present study was the different educational and cultural contexts of the groups, since the classes that were observed showed some differences either in the professors' teaching method or differences in students' seriousness, attentiveness, motivation, ect., a problem also identified by Butler and Lee (2010), Hamp-Lyons, (2007) and Oscarson(1997). Another limitation in this research that might have affected the results would be with the type of items made in each group. For example in the SA group, students designed mostly multiplechoice items, then true-false, fill-in-the-blanks with very rare cases of short-answer items. But in the PA group, open-ended type questions were the most frequent ones, followed by some multiple-choice and rare cases of true-false and fill-in-the-blank items. In the TA group, except for the first assessment which consisted of shortanswer and fill-in-the-blank items, as students wished to have multiple-choice items, and this is why all three remaining assessments were used multiple choice format. Furthermore, the pre-test and post-tests both used multiple-choice items, which while was a contributing factor to their reliability, may have affected their validity adversely.

What is suggested here for further research is to design studies to control for the validity and reliability of the self-, peer-, and teacher-assessments, especially for the former (McDonald \& Boud, 2003; Nicol \& Macfarlane-Dick, 2006; Orsmond etal., 2000; Stefani, 1998; Taras, 2001). Sulzen et al. (2008) identified high levels of validity for alternatives in assessment, but low levels of reliability and concluded that increasing the number of raters was effective in reliability improvement. It is assummed that students would be more likely to sharpen their rating abilities when provided with sufficient practice and training which will in turn make a higher validity possible (e.g., by giving them instruction and feedback). Some interviews may also be conducted with teachers to discover their insights regarding the assessment practices that may influence their implementation (Butler \& Lee, 2010). 


\section{References}

Abolfazli, Z., \& Sadeghi, K. (2012). The effect of assessment type (self vs. peer) on Iranian university EFL students' course achievement. Procedia Social and Behavioural Sciences.

Adams, C., \& King, K. (1995). Towards a framework for self-assessment. Innovations in Education and Training International, 32(4), 326-343.

Birdsong, T., \& Sharplin, W. (1986). Peer evaluation enhances students' critical judgment. Highway One, 9, 23-23.

Black, P., \& Wiliam, D. (1998). Assessment and classroom learning. Assessment in Education: Principles, Policy and Practice, 5(1), 7-74.

Blanche, P., \& Merino B. J. (1989). Self-assessment of foreign-language skills: Implications for teachers and researchers. Language Learning, 39(3), 313-340.

Boud, D. (1981). Toward student responsibility for learning. In D. Boud (Ed.), Developing student autonomy in learning (pp. 21-37). London: Kogan Page.

Brown, H. D. (2001). Teaching by principles: An interactive approach to language pedagogy (2nd ed.). San Francisco State University: Longman.

Brown, H. D. (1973). Affective variables in second language acquisition. Language Learning, 23, 231-44.

Brown, J. D., \& Hudson, T. (1998). The alternatives in language assessment. TESOL Quarterly, 32(4), 653-75.

Butler, Y., \& Lee, J. (2010). The effects of self-assessment among young learners of English. Language Testing, 27(1), 5.

Carver, D. J., \& Dickinson, L. (1982). Learning to be self-directed. In M. Geddes, \& G. Sturtridge (Eds.), Individualization. London: Modern English Publications.

Chang, C. C., Tseng, K. H., \& Lou, S. J. (2012). A comparative analysis of the consistency and difference among teacher-assessment, student selfassessment and peer-assessment in a web-based portfolio assessment environment for high school students. Computers $\mathcal{E}$ Education, 58, 303-320.

Dann, R. (2002). Promoting assessment as learning: Improving the learning process. New York: Rutledge.

Dickinson, L., \& Carver, D. (1980). Learning how to learn: Steps towards selfdirection in foreign language learning in schools. ELT Journal, 35(1), 1-7.

Entwhistle, N. J. (1987). A model of the teaching process. In J. T. E. Richardson, M. W. Eysenk, \& D. W. Piper (Eds.), Student learning: A research in education and cognitive psychology. Milton Keynes, UK: Open University Press.

Entwhistle, N. J. (1993). Recent research on student learning and the learning environment. Paper presented at the new developments in learning conference, Napier University, Edinburg.

Falchikov, N. (1995). Peer feedback marking: developing peer assessment. Innovation in Education and Training International, 32, 175-87.

Farhady, H. (2006). Twenty five years of living with applied linguistics, collection of articles. Tehran: Rahnama Press.

Freeman, M. (1995). Peer assessment by groups of group work. Assessment and Evaluation in Higher Education, 20, 289-300.

Gibbs, G. (1992). Improving the quality of student learning. Bristol: Technical and Educational Services Ltd. 
Hamp-Lyons, L. (2007). The impact of testing practices on teaching: Ideologies and alternatives. In J. Cummins, \& C. Davison (Eds.), The international handbook of English language teaching (pp. 487-504). Norwell, MA: Springer.

Henner-Stanchina, C., \& Holec, H. (1985). Evaluation in an autonomous learning scheme. In P. Riley (Ed.), Discourse and learning. London: Longman.

Jafarpour, A. (1991). Can naïve EFL learners estimate their own proficiency? Evaluation and Research in Education, 5, 145-157.

Lin, S.-J., Liu, Z.-F., \& Yuan, S.-M. (2001). Web-based peer assessment: Attitude and achievement. IEEE Transactions on Education, 44(2), 13.

McDonald, B., \& Boud, D. (2003). The impact of self-assessment on achievement: The effects of self-assessment training on performance in external examinations. Assessment in Education: Principles, Policy and Practice, 10(2), 209-220.

McNamara, T. (2000). Testing, testing... What is a language test. In H. G. Widdowson (Ed.), Language testing (p. 7). Oxford: Oxford University Press.

Mousavi, S. A. (2012). An encyclopaedic dictionary of language testing. Tehran: Rahnama Press.

Naiman, N., Frohlich, M., Stern, H., \& Todesco, A. (1978). The good language learner. Toronto: Ontario Institute for Studies in Education.

Nicol, D., \& Macfarlane-Dick, D. (2006). Formative assessment and self-regulated learning: A model and seven principles of good feedback practice. Studies in Higher Education, 31(2), 199-218.

Oldfield, K. A., \& McAlpine, M. K. (1995). Peer and self assessment at tertiary level: an experimental report. Assessment $\mathcal{E}$ Evaluation in Higher Education, 21, 23950.

Orsmond, P., Merry, S., \& Reiling, K. (1997). A study in self- assessment: tutor and students' perceptions of performance criteria. Assessment $\mathcal{E}$ Evaluation in Higher Education, 22, 357-67.

Orsmond, P., Merry, S., \& Reiling, K. (2000). The use of student derived marking criteria in peer and self-assessment. Assessment and Evaluation in Higher Education, 25(1), 23-38.

Oscarson, M. (1997). Self-assessment of foreign and second language proficiency. In C. Clapham, \& D. Corson (Eds.), Encyclopaedia of language and education: Language testing and assessment (pp. 175-187). Dordrecht, Netherlands: Kluwer Academic.

Paris, S. G., \& Paris, A. H. (2001). Classroom applications of research on selfregulated learning. Educational Psychology, 36(2), 89-101.

Patri, M. (2002). The influence of peer feedback on self and peer-assessment of oral skills. Language Testing, 19(1), 109-131.

Pond, K., Ul-Haq, R., \& Wade, W. (1995). Peer review: a precursor to peer assessment. Innovation in Education and Training International, 32, 314-23.

Powell, J. P. (1981). Moving towards independent learning. In D. Boud (Ed.), Developing student autonomy in learning (pp. 205-10). London: Kogan Page.

Roever, C. (2001). Web-based language testing. Language Learning \& Technology, 5(2), 84-94.

Ross, S. (1998). Self-assessment in second language testing: A meta-analysis and analysis of experimental factors. Language Testing, 15(1), 1-19. 
Sadler, P., \& Good, E. (2006). The impact of self- and peer-grading on student learning. Educational Assessment, 11(1), 1-31.

Schumann, J. H. (1975). Affective factors and the problem of age in second language acquisition. Language Learning, 25, 209-35.

Stefani, L. (1998). Assessment in partnership with learners. Assessment and Evaluation in Higher Education, 23(4), 339-350.

Stern, H. H. (1975). What can we learn from the good language learner? Canadian Modern Language Review, 31, 304-18.

Stern, H. H. (1983). Fundamental concepts of language teaching. Oxford: OUP.

Sulzen, J., Young, M., \& Hannifin, R. (2008). Reliability and validity of an ecologically- grounded student teacher electronic portfolio rubric. In K. McFerrin, et al. (Eds.), Proceedings of society for information technology \& teacher education international conference (pp. 153-159). Chesapeake, VA: AACE.

Taras, M. (2001). The use of tutor feedback and student self-assessment in summative assessment tasks: Towards transparency for students and for tutors. Assessment and Evaluation in Higher Education, 26(6), 605-614.

Topping, K. (1998). Peer assessment between students in colleges and universities. Review of Educational Research, 68, 249-276.

Wiske, M. S. (1999). What is teaching for understanding? In J. Leach, \& B. Moon (Eds.), Learners and pedagogy (pp. 230-46). London: Open University Press/Paul Chapman Publishing. 


\section{Appendix}

\section{In the name of God}

\section{Dear students}

This is a first step in the accomplishment of an MA thesis project by Zainab Abolfazli khonbi at Urmia University. This acts as a test of your current knowledge of Techniques and Principles in Language Teaching (Diana Larsen-Freeman, 2006).

All the questions are in multiple-choice format. Mark the right choice on its letter. In cases you do not know the answers simply leave them unmarked.

Your name:

Thanks for your admirable attention.

For firticy information about the present research, you may contact the researcha:

E-mail zabolateiiloseragmailicam

1. "As a ........teacher, I do not force my students to speak. They are allowed to speak when they foel they are ready."
a. task-based approach
b. communicative method
c. community language learning
d. total physical response

2. The ........ approach makes use of a curriculum which is not a predetemined product, but the resuit of an ongoing context-specific problem-posing process.
a. task-based
b. participatory
c. communicative
d. content-based

3. A teacher who used the..........approach believes that communicative competence invohes more than using language conversationaliy but aiso includes ability to read, discuss, and write about subject matter from other fields.
a. communicative
b. content-based
c. task-based
d. natural

4. A(n) .......... teacher might ask students to fill in the vocabulary words in the bianks in the modiffed cloze passage as they watch the video because he believes that vocabulary is easier to learn when there are contexnial ciues to heip convey meaning.

$\begin{array}{llll}\text { a. task-based } & \text { b. content-based } & \text { c. participatory } & \text { d. community language learning }\end{array}$ 
5. A student is very good at swing abstract pattens. He is also capable of reasoning well. Which of the following intelizgences is probably stronger in him?
a. visual/spatial
b. musical/rhythmic
c. body/kinesthetic
d. logicalmathenatic

6. A certain student who has shown to have high interpersonal inteligence is good at doing...... .
a. hands-on activities
b. project-work
b. sequential presentations
d. drawing

7. According to the communicative approach, there are some common faanres betwoen. and real communication.
a. music
b. games
c. puzzles
d. songs

8. "As a ......... toacher, I believe that leaning to communicate in another language shouid be fun and loarners should start loarning it by listening."
a. total physical response
b. communicative mechod
c. content-based approach
d. integrative approach

9. In the total physical response method, it is believed that leamers' memory is activated when they respond...
a. through their actions
b. with their hands
c. by listening
d.by writing

10. "I take care of my students' folings by creating in them the foling that they are ioarning to do something usefli. "This sentence is most probably stated by a....... teacher.
a. communicative
b. content-based
c. leaming strategy training
c. cooperative learning

11. Thich of the following is one of the foatures of truy communicative activity?
a. choice
b. speed
c. interaction
d. tum taking

12. Someone who is a(n)......... believes that there is some real vaiue to each mothod and that different methods and part of mothods should be practical in the same context.
a. interactionist
b. pluralist
c. realist
d. positivist 
13. "When my students fail to say what they want to say, I suppiy the missing language when they have trouble in explaining a concept in the target language. "Which of the following is most probably practiced by this teacher?
a. task-based approach
b. cooperative leaming
c. communicative approach
d. content-based approach

14. "I try my best to connect what happens in the classroom with what happens outside that has reievance to my students. So, I sometimes engage my students in an initial discussion about what is happening in their lives. "Which of the following is most probably practiced by this toacher?
a. participatory approach
b. natural approach
c. comprehension approach
d. cooperative approach

15. When the toaching approach invoines the toacher's job is not only to toach ianguage but to toach leaming. So, he toaches the best ways of mastering $a$ language.
a. multiple intelligence
b. strategy training
c. chain drill
d. whole person

16. A method is said to be. if the teacher chooses, from among methods, to create his own biend.
a. communicative
b. integrative
c. combinatory
d. eclectic

17. "As a ......... teacher, I believe that telling students what they should exacty do in the class gives them a sense of security."
a. total physical response
b. content-based approach
c. task-based approach
d. comnunity language leaming

18. "As a ........ teacher, I walk around in my class and encourage my students to communicate in English. When they fail to do so, I translate what they wish to say in English.
a. participatory approach
b. cooperative learning
c. content-based approach
d. community language learning 
19. "As I wantod to leam English as a foreign language through interaction with others in $T L$ and negotiation of moaning, I enrolled in a(n)........ class.
a. community language learning
b. task-based approach
c. communicative language teaching
d. participatory approach

20. Another name for body intelligence is.
a. visual
b. rhythmic
c. intrapersonal
d. kinesthetic

21. The concurrent study of language and subject matter with the form and soguence of language presentation dictated by context material is known as instruction.
a. task-based
b. collaborative
c. leamer-centered
d. content-based

22. The adivecates of Total Physical Response insist in creating.
a. psectu-passiveness
b. reflecting listening procectures
c. fostering interaction
d. low affective filter

23. "Education is most effective when it is experiencod-conterod" is the principie of........
a. cooperative learning
b. content-based instruction
c. participatory approach
d. takk-based instruction

24. In the Communicative Approach, the teacher evainates his students:
a. pronunciation as well as usage
b. fluency but not accuracy
c. accuracy but not fluency
d. accuracy as well as fluency

25. The task in which students have to listen to different parts of a total set of information they noed to complete a task is called.
a. jigsaw
b. information-gap
c. integrated
d. reasoning-gap

26. The exampies of linguistictiverbal intolligence activities are.
a. hands-on activities, feld trip
b. puzzles and games, categorization
c. note-taking, story telling
d. self-evaluation, joumal keeping 
27. Both native speakers and non-native speakers of a particular language follow a regular acadomic curriculum in.
a. theme-based language instruction
b. sheltered-language instruction
c. adjunct-language instruction
d. team-based approach

\section{Thich one is among the principies of Total Physical Response?}

a. The students' speaking should be developed before understanding of the target language.

b. Language learners are intelligent and bring the experience of already learning a language.

c. Meaning in the target language can often be conveyed through actions by the students.

d. Pattern practice belps students to form habits which enable the students to use the patterns.

29. The abuity to orient oneseif in the environment, to create mental images, and a sensitivity to shape, size, and color is called inteliligence.
a. spatial
b. logical
c. interpersonal
d. verbal

30. In the adjunct model of Content-based instruction,

a. instruction is geared to students" developing second language proficiency

b. students learn vital "life-coping" or "survival" skills such as using the telephone

c. the teacher scaffolds the linguistic content by helping what they want to say

d. students take a language course that is linked to the academic course

\section{In Communicative Language Teaching,}

a. communicative interaction encourages competition among students within groups

b. the teacher answers the students" questions by drawing on the blackboard or giving exaumles

c. the teacher moves from group to group offering advice and answering question

d. the students take tums tapping out the sentences of their choice on the word chart 
32. All of the following are among the kyy assumptions of task-based instruction EXEPT:

a. leamers can learn by interacting communicatively

b. the focus is on procuct rather than on process

c. basic elements are purposeful activities and tasks

d. activities are sequenced according to difficalty

33. One of the proncipies of cooperative learning is that students are encouraged to think in terms of "positive interdependence". This means that students think.
a. competitively
b. in isolation
c. individualistically
d. cooperatively

34. "Groups move back together to compare and combine scores" indicates the principle of ....
a. competency-based instuction
b. cooperative learning
c. participatory approach
d. content-based instruction

35. Which of the followng is impliad by "Human computer" in Community Language Loaming?

a. the teacher reads the transcript while the students listen

b. strengthening the students" independent learning

c. the teachers' consistent repetition of words or phrases

d. recording the students' conversations

"Blessed is he who sets the aim of his endeavor in life on success in seeking the knowledge of what is useful"

Thanks for your great participation 


\section{In the name of God}

\section{Your Name:}

\section{Allowed Time: 30 Min}

\section{Directions:}

You had covered the units on Grammar-Translation Method, Direct Method, Silent Way, Audio-Lingual Method. Dessugestopedia, Community Language Learning. Communicative Language Teaching. and Total Physical Response based on Tochniques and Principies in Language Teaching (Diana Larsen-Freeman, 2006) that was used as the course book. This is a course achievement test which reveals the extent to which you had learnt from your course book. All the questions are in the multiple choice format. Mark the right choice on its letter. There will be no penalty for the wrong answers.

1. "As a .........teacher, I do not force my students to speak. They are allowed to spealk when they feel they are ready."
a. Direct Mothod
b. Communicative Mothod
c. Community Language Loaming
d. Total Physical Response

2. According to the Communicative Approach to language teaching, there are some common features between and real communication.
a. music
b. games
c. puzzies
d. songs

3. "As a/an ......... teacher, I believe that leaming to communicate in another language should be fun and leamers should start leaming it by listening."
a. Total Physical Response
b. Communicative Method
c. Andio-Lingual Mothod
d. Integrative -Approach

4. In the total physical response method, it is believed that leamers' mensory is activated when they respond.
a. through their actions
b. with their hands
c. by listening
d.by writing 
5. Which of the following is one of the fearures of a truly communicative activity?
a. Choice
b. Spood
c. Interaction
d. Tum taking

6. "As a ........ teacher. I believe that telling students what they should exactly do in the class gives them a sense of security."
a. Total Physical Response
b. Dessugestopodia
c. Direct Method
d. Community Language Larning
7. The advocates of Total Physical Response insist on creating
a. psoudo-passiveness
b. refacting listoning procodures
c. fostering interaction
d. low affective fitter

8. In the Communicative Approach the teacher evaluates his students"
a. pronuciation as weil as usage
b. fuency but not accuracy
c. accuracy but not fiuency
d. accuracy as well as fuency

9. Which one is ansong the principles of Total Physical Response?

a. The students' spoaking shouid be developod before understanding the target language.

b. Language ioumers are intelligent and bring the experience of airoady leaming a language.

c. Moaning in the target language can often be conved through actions by the students.

d. Pattem practice heips students to form habits which emable the snidents to use the patteris.

10. In Communicative Language Teaching.

a. communicative interaction encourages comperition among students within groups

b. the tacher answers the students' questions by drawing on the blackboard or giving exampies

c. the toacher moves from group to group offering advice and answering question

d. the students take turns tupping out the sentences of their choice on the word chart

11. Which of the following is implied by "Human conputer" in Community Language Learning?

a. The teachers' reading of the transcript while the students are iistening

b. Strongthening the students' independent loarning

c. The teachers' consistent repetition of words or phases

d. Recarding the students' conversations 
12. What is the effect of paying attention to similarities between the target and the native language in Grammar-Translation Method?
a. Learning is faciititatod.
b. Loarning is ever-changing.
c. Loarning is blockod.
d. Loarning is limitod.

13. How is the meaning made clear in Total Physical Response method?

a. Through body movement

b. By transiating into the students' native language

c. By contrastive anabysis of native and target languages

d. By forcing the snidents 'perceptions

14. Which of the following is correct regarding Total Physical Response method?

a. The written language is amphasized over spoken language.

b. Students read in the target language (e.g. dialogs) and urite (e.g. compositions).

c. It is important that students acquire the molody of the language.

d. The spoken language is omphasizod over written language.

15. What is the role of students in Total Physical Response method?
a. Imitator
b. Communicator
c. Counsoior
d. Passive lecrner

16. In Communicative Approach, how is the cuiture viewed?

a. Cuiture is viewod as consisting of literature and fine ants.

b. Cuiture consists of the history of the poople who spoak the target language.

c. Cuinure is viowed as having wnique reality, or spirit for a particular mass of people.

d. Cuiture is the cveryday life style of the people who use the ianguage.

17. In which one of the following methods, posters displaying grammatical information about target language are hung around the room in order to take advantage of students" peripheral learning?
a. Communicative Language Teaching
b. Silent Way
c. Dessugestopodia
d. Community Language Loarning 
18. The syllabus in Direct Method is based on and
a. inguistic structures - doduction
b. situations - doduction
c. topics - situations
d. iinguistic strucheres - topics

19. Which of the following is FALSE as one of the characteristics of Audio Lingual Method?

a. Errors load to formation of bad habits.

b. Positive reinforcement heips students to dewiop correct habits.

c. Written form of the ianguage is more basic than the spooch.

d. Language cannot be soparatod from cuinure.

20. In an Audio Lingual Method, most of the interaction is between and and is initiated by the

a. students - imitators - toachers

b. students - teachor - imitators

c. toacher - students - toachor

d. students - imitatars - students

21. What is the role of a teacher in Silent Way?
a. A technician or an engineer
b. An orchestra loader
c. An imitator
d. A sckiliful grammarian

22. What is the logic to choose 'target language names' in Dessugestopedia?

a. The teacher can call the names of students easily.

b. Natrive language translation is avoidod.

c. The barriers will be reinforcod

d. Now identity makes students fool more secure.

23. In both Grammar Translation Method and Dessugestopedio, the teacher plays the role of a/an
a. coordinator
b. conductor
c. authority
d. participant 
24. "I take care of my students" feelings by creating in them the feeling that they are learning to do something useful." This sentence is most probably stated by a. teacher.
a. Communicative
b. Cognitive code
c. Direct method
d. Audio-lingual mothod

25. "When my students fail to say what they want to say. I supply the missing language when they have trouble in explaining a concept in the target language." Which of the following is most probably practiced by this teacher?
a. Cognitive Approach
b. Andio-Lingual Mothod
c. Communicative Approach
d. Suggestopodia

26. "As a ......... teacher, I walk around in my class and encourage my students to communicate in English. When they fail to do so, I translate what they wish to say in English.
a. Cognitive Code
b. Grammar Transiation Mothod
c. Communicative language taaching
d. Community Language Laaming

27. "As I wanted to learn English as a foreign languge through interaction with others in target language and negotiation of meaning. I enrolled in a class.
a. Community Language Laarning
b. Total Physical Response
c. Communicative Language Teaching
d. Direct Method

28. What is the nature of student-student interaction in Communicative Language Teaching method?

a. Students issue commands to one another as well as to the teacher.

b. Students interact a great deal with one whother.

c. Initially, the students can only respond nonverbaly or with a few words.

d. Student-student verbal interaction is desirable, so the teacher is silent.

29. As a teacher who follows the Communicative approach, which of the following areas would you most emphasize in your teaching?
a. Pronunciation
b. Vocabuiary
c. Functions
d. Structures

30. Which of the following is NOT the teacher's role in Communicative Approach?
a. Orchestra loader
b. Facilitator
c. Advisor
d. Co-communicator 
31. Inforuation gap, role plays, and games are language teaching techniques used in
a. Communicative Language Teaching
b. Audio-Lingual Mothod
c. Cognitive Code Approach
d. Dessugestopedia

32. How is the leaming process in Community Language Learning Method?
a. Dynamic and crative
b. Passive and repetitive
c. Time-consuming and useless
d. Communicative and suddon

33. Which of the following methods states that each language has phonological, morphological, and syntactic levels, and that a good language leamer is one who has enough knowledge and skill in all these levels?
a. Communicative approach
b. Direct method
c. Andio-lingual
d. Sllent way

34. In Direct Method, evaluation is accomplished by asking the students
a. to demanstrate their knowiodge
b. to draw a map
c. to read aloud a text
d. to use the language

35. Based on the Communicative approach, students should consider the L2 at is discourse level which refers to
a. authentic material
b. cuitural denelopment
c. cohesion and coherence
d. sentence structure

"Blessed is he who sets the aim of his endeavor in life on saccess in seeking the knowledge of what is useful" 